\title{
Analysis of superior commodities of capture fisheries sector at Kranji Village, Lamongan Regency
}

\author{
Tri Ayu Rachma Dewi ${ }^{1 *}$, Asri Sawiji ${ }^{1}$, Toha Muslih ${ }^{2}$ \\ Marine Science Department, Faculty of Science and Technology, UIN Sunan Ampel Surabaya, Indonesia \\ ${ }^{2}$ Marine and Fishery Office of Lamongan Regency, Indonesia \\ *E-mail: rachmadewi1425@gmail.com
}

\begin{abstract}
The fisheries sector is one of the main driver of the national economy. One area of Indonesia that has fishery potential that can be developed is Paciran District, Lamongan Regency, East Java Province. This study was conducted in Kranji Village, which is located in Paciran District and has great pelagic fishery potential. The purpose of this study is to analyze the determination of superior fish commodities from the capture fisheries sector in Kranji Village. The determination of the leading commodities is carried out based on the LQ (Location Quotient) analysis method. The fluctuation of the catch in Kranji Village is affected by various aspects such as natural conditions, the number of fishing gear and government regulations. The fishing season in Kranji Village is divided into: (1) Tuna (Thunnus sp.) season which occurs from October to April with 15 to 20 trips per month; and (2) Goldstripe Sardinella (Sardinella gibbosa) season from May to September with 7 to 12 trips per month. Fishing gear in Kranji Village consists of purse sein, gill nets, cob nets, waring and mini trawlers. This study found that LQ value $>1$ for 12 fishes species: Bali Sardinella, Goldstripe Sardinella, Torpedo Scad, Longtail Tuna, Eastern Little Tun, Narrow-barred Spanish Mackerel, Giant Fish, Black Pomfret, Dorab Wolf Hearing, Orange-spotted Spinefoot (1.065), Other Fishes (1.057), and Short-bodied Mackerel (1.007). The results indicate that 12 fishes species have a comparative advantage and increasing income and contribution to the economy of Kranji Village.
\end{abstract}

Keywords: Location Quotient, superior fish commodities, capture fisheries.

\section{INTRODUCTION}

The fisheries is a sector that can be the main driver of the national economy and one of the important sectors for the life of Indonesian people. The Indonesian fisheries sector has enormous potential. Indonesia's potential can be seen from Indonesia's waters which have an area of 5.8 million $\mathrm{km}^{2}$ (consisting of a territorial sea area of 0.3 million $\mathrm{km}^{2}$, an area of archipelagic waters 2.95 million $\mathrm{km}^{2}$, and an area of Indonesia's Exclusive Economic Zone (EEZ) of 2.55 million $\mathrm{km}^{2}$ ). As the largest maritime country in the world, Indonesia has enormous and diverse natural resources, both in the form of renewable natural resources such as fisheries. The sustainable potential of Indonesia's marine fish resources is estimated at 7.3 million tons per year, which are scattered in Indonesian territorial waters and the waters of the Indonesian EEZ. The total allowable catch (TAC) is 5.8 million tonnes per year or about 80 percent of the sustainable potential and 5.4 million tonnes of new use are utilized in 2013 or only $93 \%$ of the TAC. Total capture fisheries production in seas and lakes is 5.863 million tons. The Indonesian sea has about 8,500 fish species of which 37 percent of the world's fish species have high economic value, such as tuna, shrimp, lobster, reef fish, ornamental fish, shellfish and seaweed. This natural wealth is one of the basic assets that must be managed optimally to realize the welfare and prosperity of the Indonesian people [1].
The Indonesian fisheries sector is capable of being the main driver of the national economy based on several factors, namely: (1) Indonesia's fishery resources are large in both quantity and diversity; (2) Industry in the fishery sector has links with industries in other sectors; (3) local resource-based industries; (4) The Indonesian fishery sector has a high comparative advantage based on the potential of its fish resources. Therefore, fisheries resources have a comparative advantage as a leading sector in improving the nation's economy [2].

One area of Indonesia that has fishery potential that can be developed is Paciran District, Lamongan Regency. Paciran sub-district has a coastline length of $\pm 14.6 \mathrm{~km}$ which stretches between 12 coastal villages, namely: Blimbing, Kandangsemangkon, Paciran, Tunggul, Kranji, Banjarwati, Kemantren, Sidokelar, Paloh, Weru Village, Sidokumpul, and Warulor. Fishery and marine potential in Paciran Subdistrict include capture fisheries, fish or shrimp cultivation as well as fishery product processing and supported by other activities. The fish caught consisted of various types, among others; Thunnus sp., Rastrelliger sp., Decapterus spp., Trichiurus sp., anchovies, crab, squid, prawns, mackerel and others [3]. In marketing the fish caught by fisher, it is supported by the existence of two units of Fish Landing Center (Pangkalan Pendaratan Ikan, PPI), namely: PPI Weru 
Village and PPI Kranji Village. Production of captured fish landed at PPI Kranji reached 3,997.6 tons.

Determination of superior commodities in an area is the first step towards fisheries development based on the concept of efficiency to gain comparative and competitive advantages in facing trade globalization. Commodities have a comparative advantage in terms of both supply and demand. From the supply side, superior fish commodities are characterized by superiority in growth in the biophysical, technological and socio-economic conditions of fisher, which are used as a mainstay for increasing income. Meanwhile, superior fish commodities from the demand side are characterized by strong market demand, both domestic and international markets [4]. In identifying superior commodities, various approaches and analysis tools have been used. Each approach has advantages and disadvantages. One of the approaches used to analyze superior fish commodities is the Location Quontient (LQ) method. The purpose of this study is to determine the fluctuation of capture fisheries production, which is identified as the basis for the capture fisheries sector which can be a key sector for regional development, and to analyze the determination of superior fish commodities from the capture fisheries sector in Kranji Village using LQ method.

\section{METHODS}

This study was conducted in August-October 2020 in Kranji Village, Paciran District, Lamongan Regency. The location selection was carried out purposively with the consideration that Kranji Village is an area with considerable fishery potential and is directly adjacent to the Java Sea.

This study uses two data sources, primary data (capture fisheries problems and influencing factors) and secondary data (fish production in Kranji village and Paciran district). Then, data processing was carried out quantitatively using the LQ method.

$$
L Q=\frac{v i / v t}{V i / v t}
$$

where $v i$ is production or production value of $i$-species of fish at the village level (Kranji), $v t$ is total production of the village, $V i$ is production or production value of the $i$ species of fish at the sub-district level (Paciran), $V t$ is total production of the district [4].

The general criteria resulting from the estimation are:

1) The value of LQ $>1$ shows that the capture fishery commodity in Kranji Village is still relatively bigger than the average exploitation in the comparison district and the commodity is a superior commodity.

2) The value of $L Q=1$ indicates that the captured fishery commodity in Kranji Village is still relatively the same as the average business in the comparison district and the commodity is not a superior commodity.

3) The value of $L Q<1$ indicates that the capture fishery commodity in Kranji Village is still relatively smaller than the average exploitation in the comparison district and the commodity is not a leading commodity.

\section{RESULTS AND DISCUSSIONS \\ Capture Fisheries in Kranji Village}

The fluctuation of the catch in Kranji Village is influenced by various aspects such as natural conditions, the number of fishing gear and government regulations. Several factors that influence fish catch fluctuations include the presence of fish, the number of fishing efforts, the success rate of fishing operations [5]. In general, catch data from 2015 to 2019 is presented in Figure-1.

Capture fisheries production in 2015 amounted to 3,829 tons, in 2016 amounted to 3,179 tons, in 2017 amounted to 2,825 tons, in 2018 amounted to 4,296 tons, in 2019 amounted to 4,365 tons. The highest production occurred in November 2019 amounting to 949 tons and the lowest production occurred in December 2015 at 45 tons. The ups and downs of the catch in Kranji Village are influenced by various factors such as fishing grounds, seasons, weather, moon conditions and nonenvironmentally friendly fishing gear. Other factors that influence the determination of fishing grounds are the moon, rain and season [6].

The fishing season in Kranji Village is divided into two. The Tuna (Thunnus sp.) season occurs from October to April with 15 to 20 trips in one month. Meanwhile, during the Goldstripe Sardinella season from May to September, the number of trips in a month is 7 to 12 trips.

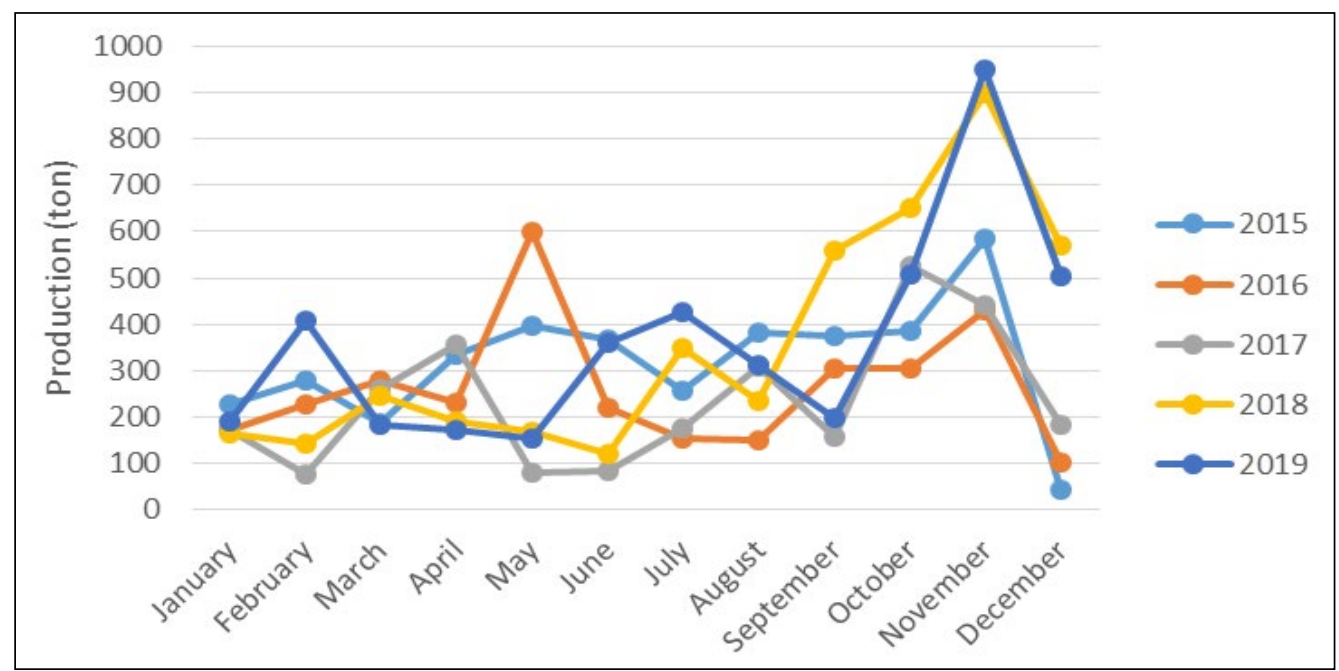

Figure-1. Fluctuations in the capture fisheries production of Kranji Village in 2015-2019 [5] 
Determination of fishing grounds in Kranji Village still uses traditional methods, based on instinct or experience that has been passed down from generation to generation and also observes the condition of the waters. Determination of the time to spread the nets in Kranji Village on a mini purse sein boat between 11 Gross Tonnage (GT) to 30 GT is carried out by a tekong or ship captain. A tekong sees the condition of the waters from the front of the ship and then directs them to the fish schools. During the Tuna season, the fishing area is 50 to 75 miles north of Kranji Village to Madura Island and Bawean Island within 5 to 7 hours drive. Meanwhile, during the Goldstripe sardinella season, the fishing area is 5 miles away in 2 to 3 hours drive.

Fishing gear is the means and equipment used in catching fish. Fishing gear in Kranji Village consists of purse sein, gill nets or gillnet, cob nets, srool or waring and mini trawlers. Mini trawl is one type of fishing gear that affects water conditions where the operating system is carried out from the bottom of the water to the surface of the water. This tool has a wing that functions to lead the target towards the mouth of the net and will gather in the cod end.

The sustainability of capture fisheries in Kranji Village is studied based on several aspects as follows:

1. Ecological Aspects

In terms of ecology, the increase in production since 2015-2019 has put pressure on aquatic resources. Based on the results of interviews, the number of fish catches is uncertain because the presence of fish is difficult to observe.

2. Economic Aspects

The development of capture fisheries in Kranji Village is characterized by the increasing number of fishing gear and facilities. The fishing gear in Kranji Village consists of purse sein, mini trawl, gill nets, and cob nets. The fishing facilities in 2020 include 32 purse sein vessels over 10 GT, 985 GT vessels with gill nets, and 20 mini trawl boats.

3. Social Aspects

The sustainability of capture fisheries in Kranji Village is reviewed based on the number of actors and the number of incidents of conflict between actors utilizing fishery resources. The number of fisher in Kranji Village is 980 people. Based on the results of the interview, it is known that there has been a conflict between fisher while at sea due to fighting over fishing areas during the tuna season. The conflict did not occur for a long time, so it did not significantly affect the social life of fisher.

4. Institutional Aspects

Capture fisheries sustainability in terms of institutional aspects in Kranji Village are the existence of Tongkol joint venture cooperatives (Koperasi Serba Usaha, KSU) and fisher association. The existence of Tongkol KSU aims to increase the income of members.

\section{Featured Commodities}

The superior catch fisheries commodity determined after conducting a Location Quotient (LQ) analysis. The analysis results are presented in Table-1. Based on the calculation of the LQ value, Table-1 shows that Short-bodied Mackerel (1.007), Bali Sardinella (1.065), Goldstripe Sardinella (1.065), Torpedo Scad (1.065), Longtail Tuna (1.065), Eastern Little Tun (1.065), Narrow-barred Spanish Mackerel (1,065), Giant Fish (1,065), Black Pomfret (1,065), Dorab Wolf Hearing $(1,065)$, Orange-spotted Spinefoot $(1,065)$, and other fishes (1.057) had comparative advantages in Kranji Village. This value indicates that the fishes have the potential to be developed in Kranji Village to increase income and contribute to the economy of Kranji Village. The fishes are basic commodity and are able to supply to other areas.

The following are types of superior capture fisheries commodities in Kranji Village:

1. Short-bodied Mackerel (Rastrelliger brachysoma) Short-bodied Mackerel (Figure-2) is a small pelagic fish that eats large plankton. Mackerel has high economic value in the fisheries sector. Mackerel also has high nutritional content at an affordable price ranging from Rp. 10,900 per kilogram. The dominant Mackerel were caught using purse sein with an average production volume of 2015-2019 of 47.2 tons per year. The marketing distribution of Mackerel in Kranji Village is usually sold directly by fisher to collectors or agents, then agents sell to consumers through the market or directly sent to factories.

2. Bali Sardinella (Sardinella lemuru)

Bali Sardinella (Figure-3) are small plankton-eating pelagic fish that live off the coast, coastal waters and deep seas. Bali Sardinella is an important economical fish species because it has a high market value with a high production volume and high production power. Bali Sardinella has a price ranging from Rp. 1,500 per kilogram. The dominant Bali Sardinella caught using purse sein with an average production volume of 2015-2019 of 159.2 tons per year. The marketing distribution of Bali Sardinella in Kranji Village is usually sold directly by fisher to collectors or agents, then agents sell to consumers through the market or directly sent to fish processing factories such as sardines.

3. Goldstripe Sardinella (Sardinella gibbosa) Goldstripe Sardinella (local name: Belo) (Figure-4) is one type of fish that has a dominant production in Kranji Village. Many people like to consume Goldstripe Sardinella because the price of Goldstripe Sardinella is affordable for the community, ranging from Rp. 2,810.00 per kilogram. The dominant Goldstripe Sardinella caught using purse sein with an average production volume of 2015-2019 of 1,494.8 tons per year. The marketing distribution of Goldstripe Sardinella is usually sold directly by fisher to collectors or agents who in turn sell agents to consumers either through the market or to fishery product processing companies such as sardines manufacturing factories. In addition, the distribution of Goldstripe Sardinella is sent directly to other regions. 
Table-1. The value of Location Quotient (LQ) calculation

\begin{tabular}{|c|c|c|c|c|c|c|c|c|}
\hline No & Types of Fish & 2015 & 2016 & 2017 & 2018 & 2019 & 2020 & LQ \\
\hline \multicolumn{9}{|l|}{ Fish } \\
\hline 1 & Anchovies & 0 & 0 & - & - & 0 & 0,007 & 0 \\
\hline 2 & Anchovy & 0 & 0 & 0 & 0 & 1 & 0 & 0 \\
\hline 3 & $\begin{array}{l}\text { Mullet/Blue-spot } \\
\text { mullet/Blue-tail mullet }\end{array}$ & 1 & 0 & 1 & 1 & 1 & 0 & 0 \\
\hline 4 & Needle fish & 0 & 0 & 0 & 1 & 0 & 0 & 0 \\
\hline 5 & Rainbow sardine & 1 & 0 & 0 & 1 & 0 & 0 & 0 \\
\hline 6 & Indian mackerel & 1 & 1 & 1 & 1 & 0 & 0 & 0 \\
\hline 7 & Short-bodied mackerel & 1 & 1 & 1 & 1 & 1 & 0,916 & 1,007 \\
\hline 8 & Scad & 1 & 1 & 2 & 0 & 0 & 0 & 0 \\
\hline 9 & Bali sardinella & 1 & 1 & 1 & 1 & 1 & 1,073 & 1,065 \\
\hline 10 & Spotted sardinella & 0 & 0 & 0 & 0 & 1 & 1,073 & 0 \\
\hline 11 & Trevallies & 1 & 1 & 1 & 1 & 0 & 1,073 & 0 \\
\hline 12 & Goldstripe sardinella & 1 & 1 & 1 & 1 & 1 & 1,073 & 1,065 \\
\hline 13 & Torpedo scad & 1 & 1 & 1 & 1 & 1 & 1,073 & 1,065 \\
\hline 14 & Other fishes & 1 & 1 & 1 & 1 & 1 & 1,073 & 1,057 \\
\hline 15 & Longtail tuna & 1 & 1 & 1 & 1 & 1 & 1,073 & 1,065 \\
\hline 16 & Eastern little tun & 1 & 1 & 1 & 1 & 1 & 1,073 & 1,065 \\
\hline 17 & Frigate tuna & 1 & 1 & 3 & 1 & 1 & 0 & 0 \\
\hline 18 & Commond dolphin fish & 1 & 1 & 1 & 1 & 0 & 1,073 & 0 \\
\hline 19 & $\begin{array}{l}\text { Narrow-barred spanish } \\
\text { mackerel }\end{array}$ & 1 & 1 & 1 & 1 & 1 & 1,073 & 1,065 \\
\hline 20 & Giant Fish & 1 & 1 & 1 & 1 & 1 & 1,073 & 1,065 \\
\hline 21 & Jack trevallies & 1 & 1 & 1 & 1 & 0 & 1,073 & 0 \\
\hline 22 & Black pomfret & 1 & 1 & 1 & 1 & 1 & 1,073 & 1,065 \\
\hline 23 & Dorab wolf hearing & 1 & 1 & 1 & 1 & 1 & 1,073 & 1,065 \\
\hline 24 & Slipmouths/Pony fishes & 1 & 0 & - & 0 & 0 & 0 & 0 \\
\hline 25 & Barramundi & 0 & 0 & 0 & 1 & 0 & 0 & 0 \\
\hline 26 & Red snappers & 0 & 1 & 1 & 1 & 0 & 0 & 0 \\
\hline 27 & Purple-spotted/Big eye & 1 & 1 & 1 & 0 & 1 & 0 & 0 \\
\hline 28 & Croackers & 1 & 1 & 0 & 0 & 1 & 0,219 & 0,542 \\
\hline 29 & Great barracuda & 1 & 1 & 1 & 1 & 0 & 0 & 0 \\
\hline 30 & Hairtails & 1 & 1 & 1 & 0 & 0 & 0,086 & 0,556 \\
\hline 31 & Barhed sipnefoot & 1 & 0 & 0 & 0 & 0 & 0 & 0 \\
\hline 32 & $\begin{array}{l}\text { Orange-spotted } \\
\text { spinefoot }\end{array}$ & 1 & 1 & 1 & 1 & 1 & 1,073 & 1,065 \\
\hline 33 & Others & 1 & 1 & 1 & 0 & 1 & 0,105 & 0,696 \\
\hline \multicolumn{9}{|c|}{ Crustacean } \\
\hline 1 & $\begin{array}{l}\text { Shrimps, Rea } \\
\text { areasiback }\end{array}$ & 0 & 0 & 0 & 0 & 0 & 0 & 0 \\
\hline 2 & $\begin{array}{l}\text { White srimp/Indian } \\
\text { banana }\end{array}$ & - & 0 & 0 & 0 & 0 & 0,020 & 0,064 \\
\hline 3 & Other shrimp & 0 & - & - & 0 & 0 & 0 & 0 \\
\hline \multicolumn{9}{|c|}{ Mollusc } \\
\hline 1 & Commond squids & 1 & 1 & 1 & 1 & 0 & 0,105 & 0,601 \\
\hline
\end{tabular}




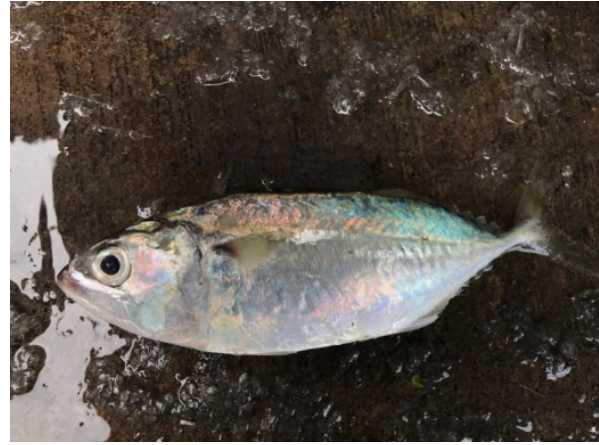

Figure-2. Short-bodied Mackerel

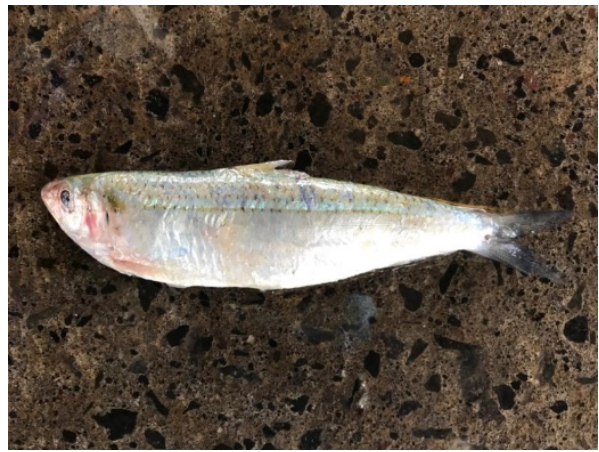

Figure-3. Bali Sardinella

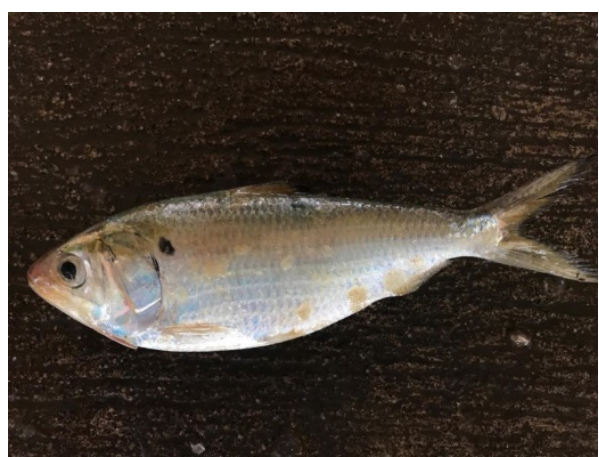

Figure-4. Goldstripe Sardinella

\section{Torpedo Scad (Megalaspis cordyla)}

Torpedo Scad (Figure-5), local names Monggo (adult size) and Kotok (juvenile size), is a type of pelagic fish that has dominant production in Kranji Village. Many people like to consume Torpedo Scad because the price is affordable for the community, ranging from Rp. 2,810.00 per kilogram. The dominant fish caught using purse sein with an average production volume of 2015-2019 of 27.6 tons per year. The marketing distribution of torpedo scad is usually sold directly by fisher to collectors or agents, who in turn sell agents to consumers either through the market, or to small baskets then to consumers.

\section{Other Fishes}

Other fishes (Figure-6) is a mixture of anchovies and small fish. The fishes have prices ranging from Rp. $1,399.00$ per kilogram. Other fishes are predominantly caught using purse sein with an average production volume of 2015-2019 of 149 tons per year. The marketing distribution of the fishes is usually sold directly by fisher to collectors or agents, who then sell to fish meal or animal feed processing factories.

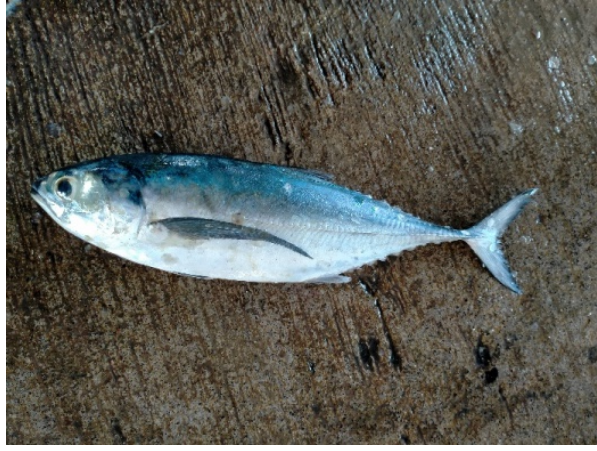

Figure-5. Torpedo scad

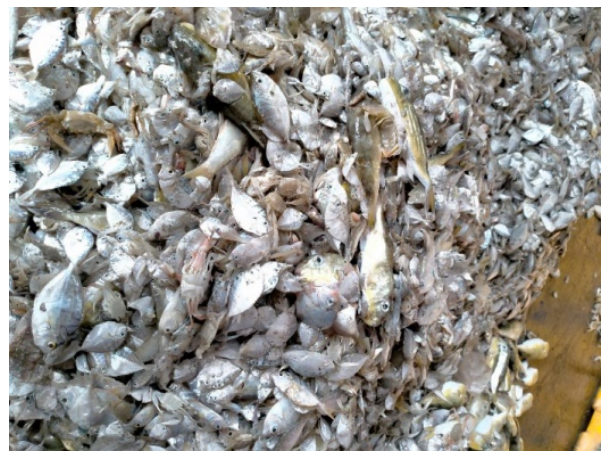

Figure-6. Other fishes

6. Longtail Tuna (Thunnus tonggol)

Longtail Tuna (Figure-7) is a large pelagic fish that has dominant production in Kranji Village. Longtail Tuna is a fast swimmer and the distribution area throughout the coast, off the coast of Indonesian waters. Longtail Tuna is a fish that is clustered in large numbers. Longtail Tuna has the local name Tongkol Walang. The price of Longtail Tuna ranges from Rp. 17,000 per kilogram. The dominant Longtail Tuna was caught using purse sein and tuna net with an average production volume of 2015-2019 of 1,536.8 tons per year. The marketing distribution of Longtail Tuna is usually sold directly by fishermen to collectors or agents, which then the agent sells to consumers either through the market, or to small baskets then to consumers. Longtail Tuna also marketing to other islands such as Bali.

7. Eastern Little Tun (Euthynnus affinis)

Eastern Little Tun (Figure-8) is a large group of pelagic fish that has dominant production in Kranji Village and has high economic value. Eastern Little Tun has the local name Tongkol Lorek because it has a line on the back of the fish. The price of this fish ranges from Rp. 12,600 per kilogram. Dominant Eastern Little Tun is caught using tuna net, but other fishing gear such as gillnet and purse sein can catch tuna in small quantities. The amount of Eastern Little Tun production on average 2015-2019 is 273 tons per year. The marketing distribution of Eastern Little Tun is usually sold directly by fisher to collectors or agents, which then the agent sells to consumers either through the market, or to small baskets then to consumers. Eastern Little Tun marketing to outside islands such as Bali. 


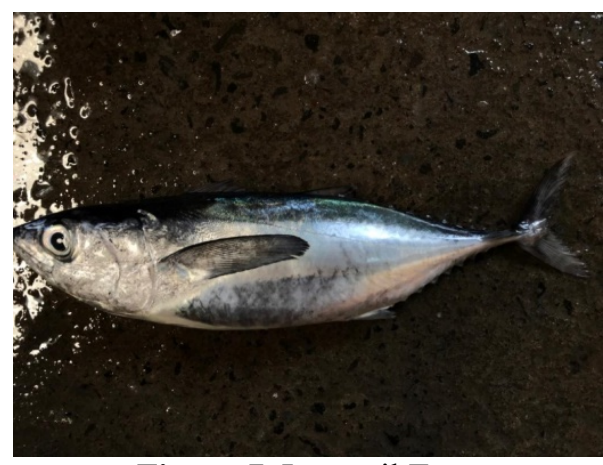

Figure-7. Longtail Tuna

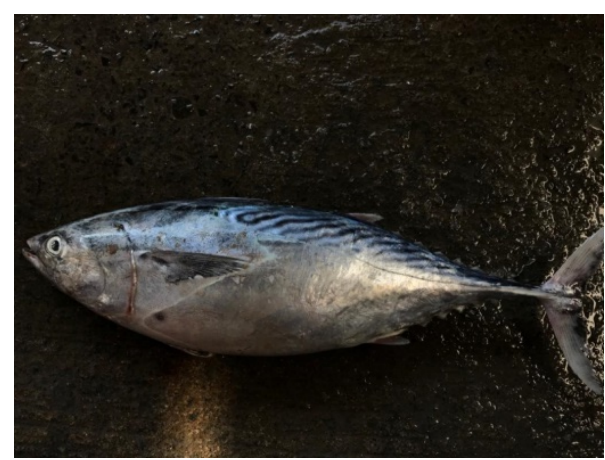

Figure-8. Eastern Little Tun

8. Narrow-barred Spanish Mackerel (Acanthocybium solandri)

One type of seawater fish from the large pelagic fish group that has high economic value is mackerel. Narrow-barred Spanish Mackerel are found in Indonesian waters such as the north coast of Java and the south coast of Java. Narrow-barred Spanish Mackerel live alone, but the catch of the fisher in Kranji Village is quite a lot because the fishing area is near the FADs where Narrow-barred Spanish Mackerel forage in the form of small fish and squid. Narrow-barred Spanish Mackerel is an export commodity in Kranji Village. The price of Narrowbarred Spanish Mackerel is Rp. 37,100.00 per kilogram. This Mackerel is caught using purse sein with resin lamps and gillnet fishing gear with an average production volume of 2015-2019 of 18.4 tons per year. Usually fisher sell Narrow-barred Spanish Mackerel to baskets or agents which are then packed in refrigeration for export.

9. Giant Fish (Arius thalassinus)

Giant Fish is one of the traditional fish, live in bottom and river estuary. The spread of this fish throughout the coastal waters, off the coast of Indonesia, especially Java. Giant fish caught using fishing gear mines, gill nets or and fishing rods with an average production amount of 2015-2019 of 55 tons per year. The marketing distribution of Giant Fish is usually sold directly by fisher to collectors or agents, who in turn sell agents to consumers either through the market, or to small baskets then to consumers.

10. Black Pomfret (Formio niger)

One type of sea water fish that has high economic value is Black Pomfret (Figure-9). Black Pomfret are found in Indonesian waters such as the north coast of Java and the south coast of Java. Black Pomfret live in groups sometimes with flying fish around Fish Aggregating Devices (FADs). Black Pomfret is an export commodity in Kranji Village with the local name Dorang. The price of Black Pomfret is Rp. 26,248 per kilogram. Black Pomfret caught using purse sein with resin lamps as well as gillnet with an average production amount of 20152019 of 12.6 tons per year. Usually fisher sell mackerel to baskets or agents which are then packed in refrigeration for export. Marketing of Black Pomfret in fresh condition.

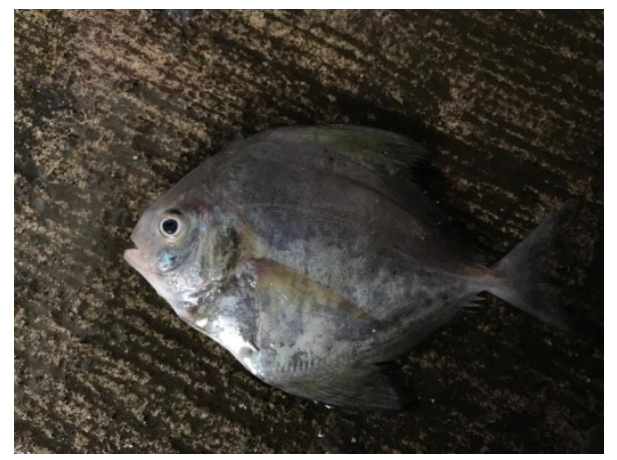

Figure-9. Black Pomfret

11. Dorab Wolf Hearing (Chirocentrus dorab)

Dorab Wolf Hearing (Figure-10) has a local name Mlido. Dorab Wolf Hearing have high nutritional content at an affordable price ranging from Rp. 7,000 per kilogram. The dominant machete fish was caught using purse sein with an average production volume of 2015-2019 13.6 tons per year. The marketing distribution of Dorab Wolf Hearing in Kranji Village is usually sold directly by fisher to collectors or agents, then agents sell to consumers through the market.

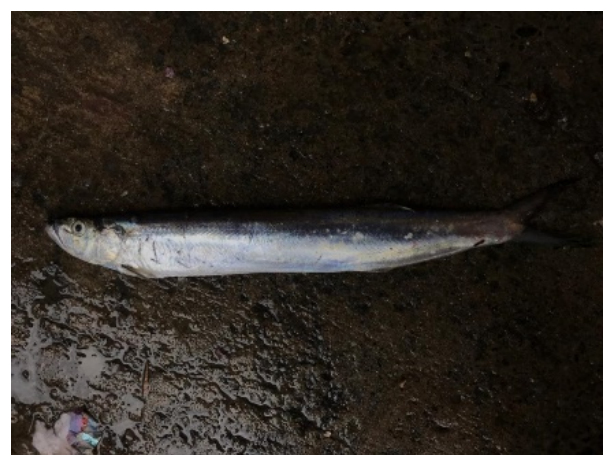

Figure-10. Dorab wolf hearing

12. Orange-spotted Spinefoot (Siganus sp.)

Orange-spotted Spinefoot is a type of demersal fish that lives on or near the bottom of the water. Coral reef areas and seagrass beds are habitat for Orangespotted Spinefoot because Orange-spotted Spinefoot are herbivorous fish. The diversity of Orange-spotted Spinefoot in Indonesia's marine waters is high. Orange-spotted Spinefoot have a fairly high economic value. Orange-spotted Spinefoot are used as consumption and protein needs of the community and become an export commodity for Indonesia. 
The dominant Orange-spotted Spinefoot were caught using mini trawl with an average production volume of 2015-2019 of 2.2 tons per year.

\section{CONCLUSIONS}

Capture fisheries production in Kranji Village has fluctuated in 2015 amounting to 3,829 tons, 2016 amounting to 3,179 tons, 2017 amounting to 2,825 tons, in 2018 amounting to 4,296 tons, and in 2019 amounting to 4,365 tons. The fluctuation of capture fishery production in Kranji Village is influenced by several factors such as fishing area, weather, moon conditions and fishing gear. Capture fisheries commodities that are superior in Kranji Village are, Bali Sardinella (1.065), Goldstripe Sardinella (1.065), Torpedo Scad (1.065), Longtail Tuna (1.065), Eastern Little Tun (1.065), Narrow-barred Spanish Mackerel $(1,065)$, Giant Fish $(1,065)$, Black Pomfret $(1,065)$, Dorab Wolf Hearing $(1,065)$, Orange-spotted Spinefoot $(1,065)$, Other Fishes (1.057), and Short-bodied Mackerel (1.007).

\section{REFERENCES}

[1] Kementerian Kelautan dan Perikanan. 2017. Rencana Strategis Kementerian Kelautan dan Perikanan Tahun 2015-2019. Kementerian Kelautan dan Perikanan Republik Indonesia. Jakarta.

[2] Fadillah, A., dan Yusalina. 2011. Analisis Daya Saing Komoditas Unggulan Perikanan Tangkap Kabupaten Sukabumi. Forum Agribisnis: Agribusiness Forum. 1(1): 39-57. https://doi.org/10.29244/fagb.1.1.39-57

[3] Marine and Fishery Office of Lamongan Regency. 2020. Fisheries Profile. Lamongan.

[4] Hendayana, R. 2003. Aplikasi Metode Location Quotient (LQ) dalam Penentuan Komoditas Unggulan Nasional. Informatika Pertanian. Vol. 12: $1-21$.

[5] Yusrizal, E. Nugraha, S. Syamsuddin, Y. Krisnafi, Z. R. Fadly. 2019. Analisis Komoditas Unggulan Perikanan Laut di PPN Brondong. Buletin JSJ. 1(1): 25-36. http://dx.doi.org/10.15578/bjsj.v1i1.8546

[6] Limbong, I., E. S. Wiyono, dan R. Yusfiandayani. 2017. Faktor-Faktor yang Mempengaruhi Hasil Produksi Unit Penangkapan Pukat Cincin di PPN Sibolga, Sumatera Utara. ALBACORE: Jurnal Penelitian Perikanan Laut. 1(1): 8997. https://doi.org/10.29244/core.1.1.89-97 